\title{
Microstructural (Cohesion and Coherence) Text Generation Problems of Syrian Refugee Students Learning Turkish
}

\author{
Sercan Demirgüneş \\ Department of Turkish Education, Omer Halisdemir University, Turkey
}

Copyright $(2017$ by authors, all rights reserved. Authors agree that this article remains permanently open access under the terms of the Creative Commons Attribution License 4.0 International License

\begin{abstract}
In language education, teaching a language as a foreign language is an emerging field compared to teaching it as a mother tongue. However, the experiences obtained in mother tongue education are adapted to teaching a language as a foreign language with various amendments and therefore progress in this field has been achieved. Council of Europe presented some common criteria for teaching a language as a foreign language and these criteria are put into practice in many countries, including Turkey, therefore Common European Framework of Reference for Languages is also applied in teaching Turkish as a foreign language. Using a microstructural analysis, this study tries to describe the problems and/or challenges in "text writing" as a product of Turkish writing act process experienced by Syrian refugees that were forced to take refuge in Turkey due to various reasons.
\end{abstract}

Keywords Common European Framework of Reference for Languages, Text Generation, Learning Process, Microstructure, Cohesion, Coherence

\section{Introduction}

Language can be defined in several ways. The history of teaching a language as a foreign language, if not as old as the language itself, dates back to ancient times. One of the most important reasons of this ancientness is historical agedness of language [13]. It is stated that in $2225 \mathrm{BC}$, Acadians conquered the land of Sumerians whose civilization was more advanced than the former and Acadians learned the Sumerian language. This event has been recorded as the first time a language, both written and oral, was taught in human history.

There is no concrete historical data for Turkish being taught as a foreign language. Although, according to Orkhon Scripts and sources belonging to Uyghur era, some hints were obtained that Turkish was learnt with non-systematic methods by foreigners, but there is no specific information about a systematic teaching of Turkish [2].

Today's modern foreign language education policies are systematically implemented by the determination of common criteria by Council of Europe. Common European Framework of Reference for Languages (CEFR) provides a common framework for foreign language education programs, textbooks etc. in all Europe. In addition to this, being able to use a foreign language with a means other than communication describes thoroughly which knowledge and skill is required to be improved. In order to deliver a successful communication, a particular set of skills and knowledge is required to be improved. These criteria, at the same time, complement to the skills that help them evaluate their own level of success in learning a foreign language at every stage of their lifelong learning process [7]. Common European Framework of Reference for Languages is a well-structured, fundamental study for foreign language education. These common criteria make it possible for language learning individuals to evaluate their own foreign language skills (listening, reading, speaking and writing) themselves [1].

Acquiring basic language skills (reading, speaking, writing, listening) is the primary and fundamental goal for both teaching Turkish as a mother tongue and as a foreign language. In teaching Turkish as a foreign language, "writing skill is not obtained naturally. It is learnt subsequently and transferred culturally from natural environments or with the help of a structured program. As writing skills should be learnt through experiences and continuous practices." [18].

In writing skill (more specifically in "text generation"), the common agreement is of the direction that the psychological and cognitive structure is arranged as "planning, transcribing and reviewing" [9, retrieved from 19). Flower and Hayes [9, 10], focused on how the writer, in the writing process, composed the words or structural forms in the cognitive base. In the aforementioned study, only 
rhetorical problems were stated; the emphasis was not put on whether the writer had other problems or not. As [21] states, the natural environment and the mother tongue of the individual, who tries to learn the writing skill, and also the target language/environment, where the individual resides, is quite influential in the learning curve of that particular individual.

There is a serious interaction between the student's mother tongue and the target language in the learning process of the individual, and during the interaction process some transfers are eventuated. This code shifting or copying may appear positively, negatively or fundamentally [see. 16]. At the same time, the copying from the student's mother tongue to the target language occurs as global copying or selective copying [16]. This process is sometimes realized by the student himself consciously and sometimes comes out as an implicit behavior within the learning process.

In situations where the copying is transferred formally wrong, for instance plural structures in a foreigner's mother tongue (assuming she/he is English and learning Turkish) are constructed as "two apples", in which the word before the noun states plurality and the noun gets plural suffix, it is probable that she/he transfers it directly to Turkish: two apples. However, in Turkish the structure of "Tr. iki elmalar (Ing. two apples)" is not accepted. In such a structure, when the word before the noun states a numerical plurality, the noun does not require a plural suffix: "Tr. iki elma (Ing. two apples)". Apart from this and similar formal factors, it is important to determine semantic comprehensions of the target language that the foreign language student is learning. In this respect, it will be convenient to mention textuality criteria, especially text-centered textuality criteria, which are frequently mentioned in the literature and currently being studied.

As a product of writing skill, text has two directly observable criteria. They are called "cohesion" and "coherence" under the title of intra-textual criteria. As it is already known, for a text to be a text, these criteria are essential and they are specified as "cohesion, coherence, reasonableness, contingency, informativity, intertextual relation" by [4]. In educational studies based on linguistics insight "the textual metafunction is considered by focusing on cohesion, and the multimodal use of cohesive devices such as repetition, reference, omission, substitution, and intertextual reference and coherence [22]". In language education, not only the teaching of grammatical rules or formal elements - here, indirectly, cohesion is in the foreground - [8], but also the teaching of various language skills and the usage of such skills as responsibility and courage, attitude, and coherence in target language should be provided.
In this respect, measurement of writing skill should be analyzed on the basis of these two criteria (cohesion and coherence) and many studies in the literature focuses on cohesion and coherence in texts. Studies in the area of second language acquisition and education are mostly constituted on cohesion and coherence [5]. Apart from cohesion and coherence, and basically covering these criteria, three structures come into prominence in analyzing a text:

Microstructure: It refers to an arrangement between clauses. Determination of structures such as references, elliptical forms, agglutination elements is a microstructural analysis.

Macrostructure: It is a portrayal that addresses to the main sections of the text in the context of plot, narrative program, narrator, etc.

Superstructure: It refers to essential characteristics that every text has. Text types and sorts, and out of context comments are related with superstructure [11].

Cohesion requires a clear lexical and grammatical formal coding. [12] studies cohesion in two parts: grammatical cohesion and lexical cohesion ${ }^{1}$. [12] classifies grammatical cohesion into four major categories:

a) Reference: It takes in two forms: endophora, the interpretation of reference lies within the text, and exophora the interpretation of reference lies beyond the text.

b) Substitution: Very similar to ellipsis, substitution is the replacement of one item with another. Substitution can take place in three forms; verbal substitution, nominal substitution and clausal substitution.

c) Ellipsis, unlike substitution, is the omission of the item and where there is ellipsis, there is a presupposition, in the structure that something is to be supplied or 'understood'.

d) Conjunctions are formal patterns that provide a text to be lined up with a logical succession (for detailed information, see 12).

According to [12], cohesion is a fact already in the text, in other words, in the formation of cohesion the reader/receiver does not have any contribution. However, these approaches of the aforementioned two researchers have been criticized. It is usual to come across with texts (see Table 1) that do not have formal characteristics of cohesion but are read and understood and known to receivers/readers as coherent and consistent [14]:

Therefore, cohesion and coherence notions are not prerequisite for one another even though they are mentioned in the text. Even when there is a problematic and a lacking structure regarding the cohesion elements like in the invitation sample below, the reader can make this text meaningful and coherent with his background and world knowledge:

1 Lexical cohesion is not included as it is out of the scope of this study. Analysis of Reiteration and collocation notions shall widen the scope of this study and take away the study from its aim. 
Table 1. Invitation sample

\author{
Necip Mahfuzla Söyleși \\ “Arap Romanında Dini ve Folklorik Mirasın \\ İslevselleştirilmesi” \\ Perșembe: Akşam Saat Yedi, İbn-i Haldun \\ Salonu \\ Herkese Açık Davet
}

\section{Talk with Necip Mahfuz \\ "Functionalization of Religious and Folkloric Heritage in Arabian Novel"}

Thursday, 7 pm., Ibn-i Haldun Hall

\section{Public Invitation}

Coherence refers to focusing on lexical relations more than formal patterns of text. Comprehensiveness, coherence and transparency [7], as well as precision, play a great role in developing intercultural communicative awareness and competence among learners [20] and this can be introduced and developed by language teachers.

Coherence relations in a text also provide readers with various hints about the main way of thinking belonging to the writer. As the writer cannot separate the case, the incident or the thoughts he revealed (even in his fictitious texts where he recreates a new world) from his own personal background and world knowledge. This is valid for all individuals.

Hume (1748) dealt with coherence as a way of thinking and [17] divided it into three main types. Studies regarding the types of coherence relations and text analyses in this field accelerated undoubtedly with the studies of Mann and Thompson (1986, 1987) [17]. [17]'s coherence relations appear simpler and applicable in terms of text analyses: a) resemblance relations, b) cause-effect relations, c) contiguity relations [for detailed information see [17]:

1. Resemblance relations: Resemblance relation is analyzed in six different styles of thinking:

a Parallel: It is formed by two propositions and both propositions have the same value:

b Dick Gephardt organized rallies for Gore, and Tom Daschle distributed pamphlets for him [17].

c Contrast: We can change the example phrases of Parallel and, generally, re-form it by using conjunctions such as but, however, etc.:

d Gephardt supported Gore, but Armey opposed him.

e Exemplification: In here, containment relation is in the foreground, and primary proposition contains the consequent proposition semantically:

f Young aspiring politicians often support their party's presidential candidate. For instance, Bayh campaigned hard for Gore in 2000 [17].

g Generalization: Here, containment relation in exemplification is reversed:

h Bayh campaigned hard for Gore in 2000. Young aspiring politicians often support their party's presidential candidate.

$$
\begin{aligned}
& \text { حوار مع نجيب محفوظ } \\
& \text { "توظيف الموروثات الدينية والثعبية في الرواية العربية" } \\
& \text { الخميس: السابعة مساء، قاعة ابن خلدون } \\
& \text { الدعوة عامة - ماعة }
\end{aligned}
$$

i Exception: Introduced with primary proposition, notion map is excluded with exception via using consequent proposition, and exception can be observed through "although, nevertheless" structures.

Young aspiring politicians often support their party's presidential candidate. However, Rudy Guilliani supported Mario Cuomo in 1994.

or

Rudy Guilliani supported Mario Cuomo in 1994. Nonetheless, young aspiring politicians often support their party's presidential candidate.

a Elaboration: Phrase form that takes place in the primary proposition is introduced in details in consequent proposition:

A young aspiring politician was arrested in Texas today. John Smith, 34, was nabbed in a Houston law firm while attempting to embezzle funds for his campaign.

2. Cause-Effect relations are analyzed in four parts:

a. Result: Consequent proposition is an inference of primary proposition [17]:

"George is a politician, and therefore he's dishonest"

b. Explanation: Reversed form of result relation:

"George is dishonest, because he's a politician." or

"George is dishonest. He's a politician" [17]

c. Violated Expectation: Resembles to the result relation; second proposition is established with the expected consequent proposition by the semantical inference of primary proposition or with the reverse of "Result".

"George is a politician, but he's honest".

d. Denial of Preventer: Reverse of Violated Expectation

"George is honest, even though he's a politician." [17]

3. Contiguity relations: Dealt with two different forms of occasion relations (Situation 1 and Situation 2). Contiguity relation is essentially in the same form as occasion in the way it is dealt by Hobbs (1900). In both propositions, there is a temporal rank between propositions:

George picked up the speech. He began to read. [17].

\section{Aim}

The aim of this study is to analyze and describe the written texts of Syrian refugee students who learn Turkish in Ömer Halisdemir University Turkish Education Application and Research Center within a program framework that uses 
European Language Portfolio and students are graded in A1, $\mathrm{B} 1$ and $\mathrm{C} 1$, in terms of microstructural elements; cohesion and coherence. In this regard, a Cohesion Measurement Tool (ANNEX 1), adjusted to the typology of Turkish, is formed based on [12] and with the contributions of [23] and [15] and these texts are analyzed according to this tool. As for coherence, coherence relations in written texts are analyzed by taking [17] as a basis by researchers.

\section{Data Collection and Method}

In line with the study, separate and elective questions for each level were prepared for the Syrian students learning Turkish in Ömer Halisdemir University Turkish Education Application and Research Center, in accordance with the acquisition of writing skill that is one of the main skills of Common European Framework of Reference for Languages: Learning-Teaching and Assessment [3]. Students formed a text by choosing one of the questions prepared for each level.

The following questions were directed to 17 students in A1 level and students responded to one question they preferred. Therefore a database of 1989 words and 382 sentences has been formed:

a (Tr) Geçen yıl nasıl bir hayatın vardı? Neredeydin? $\mathrm{Ne}(\mathrm{ler})$ yapıyordun? vb. sorularına yanıt veren bir metin oluşturunuz.

[a. (Ing) Form a text that responds to questions such as How was your life last year? Where were you? What were you doing?]

b (Tr.) Başka bir ülkede yaşayan bir arkadaşınıza hayatınızı anlatan, duygu ve düşüncelerinizi ifade eden bir mektup yazınız.

[b. (Ing.) Write a letter that describes your life, feelings and thoughts to a friend of yours who lives in another country.]

c (Tr.) Gezdiğiniz şehirlerden birini/kendi şehrinizi tanıtınız. Şehrin tarihi, kültürü, turistik yerleri, yemekleri hakkında bilgi veriniz.

[c. (Ing.) Introduce one of the cities you visited/your city. Give information about the history, culture, touristic places, cuisine of the city.]

Three elective questions below were directed to 20 students in B1 level, and a database of 2733 words and 347 sentences has been formed:

a (Tr.) Ülkenizden bir arkadaşınız size Türkiye'de eğitim almayı düşündüğünü söyleyen bir e-posta yazmış. Sizden başvuru şartları, Türkiye'deki yaşam koşulları hakkında bilgi vermenizi istiyor. Arkadaşınıza Türkiye'de yaşamak ve eğitim almak ile ilgili genel bilgiler veren bir e-posta yazını. E-postanızda Türkiye'de eğitim almayı önerebilir ya da önermeyebilirsiniz. Her iki durum için nedenlerinizi ayrıntılı olarak açıklayınız. [a. (Ing.) One of your friends from your country sent you an e-mail about his idea of getting education in Turkey. He/She asks you for application rules, about living conditions in Turkey. Write your friend an e-mail giving general information about living and getting education in Turkey. In your e-mail, you may or may not recommend getting education in Turkey. Describe in details your reasons for both situations.]

b (Tr.) Hayattaki en büyük pişmanlığınız nedir? Keşke öyle yapmasaydım ya da öyle davranmasaydım dediğiniz durumlar var mi? Şimdi aynı durumda olsaydınız farklı davranır mıydınız? Eğer farklı davranırdım diyorsanız nasıl davranırdınız? Bu olay(lar) sizi nasıl etkiledi ve değiştirdi?

[b. (Ing.) What is your biggest regret in life? Are there any situations in which you wish you did or did not behave that way? Would you behave differently, if you were in the same situation now? If you say yes, how would you behave? How did these incident(s) affect and change you?]

c (Tr.) Son dönemlerde özellikle gençler arasında yaygın olan marka takıntısı hakkında neler düşünüyorsunuz? "Marka" ne demektir ve markanın önemi nedir? Marka takıntısı sadece kıyafet alırken mi kendisini gösterir yoksa başka alanlarda da marka takıntısından söz edebilir miyiz? Sizin marka merakınız var mi? İnsanlardaki marka takıntılarının nedenleri neler olabilir?

[c. (Ing.) What do you think about the brand obsession that is especially common between the young recently? What is "brand" and what is its importance? Does brand obsession appear whilst only buying clothes or can we mention about it in other areas? Do you have a brand obsession? What do you think about the reasons of brand obsession of people?]

In $\mathrm{C} 1$ level, 19 students answered one of the two questions below, and a database of 2856 words and 301 sentences has been formed:

a (Tr.) Yeni bir dil öğrenmek neden önemlidir? Dil öğrenmek insana neler katar, insanın hayatında neleri değiştirir? Farklı diller bilmek insanın kariyerine ve sosyal hayatına katkıda bulunur mu? Türkçe öğrenmek sizin hayatınızda neler değiştirdi? Kendi dil öğrenim sürecinizin de örnekler vererek bu sorulara yanıt veren bir metin oluşturunuz.

[a. (Ing.) Why is it important to learn a new language? What does learning a language add to a person? What does it change in a person's life? Does speaking different languages contribute to a person's career and social life? What did learning Turkish change in your life? Form a text answering these questions by giving examples from your own language learning process.]

b (Tr.) Kahramanlar: Kendiniz, en yakın arkadaşınız, Leyla, avcı, kral, dövüşçü, karınca, robot, hırsız Zaman: Günlerden bir gün, günümüz, 100 yıl önce, 2250 yılında, gece, sabah. Mekân: Lunapark, dünya, issız ada, orman, 
uzay gemisi, uçak, saray, hapishane Yukarıdaki kahramanlar, zaman ve mekânlardan en az ikişer tanesini kullanarak bir öykü oluşturunuz.

[b. (Ing.) Heroes: Yourself, your best friend, Layla, hunter, king, fighter, ant, robot, thief Time: One fine day, nowadays, 100 years ago, in the year of 2250, night, morning. Location: Fun fair, earth, deserted island, forest, spaceship, airplane, palace, jailhouse Compose a story by using at least two of the heroes, time and locations above.]

The study is based on the analysis of the texts acquired from the database of answers to questions given by the students and the description of this database is structured with document analysis.

\section{Findings}

Cohesion and coherence facts, observed constantly without making any changes at A1, B1 and C1 levels, will be provided at the end of the section. When we look at the written texts of the students at $\mathrm{A} 1, \mathrm{~B} 1$ and $\mathrm{C} 1$ level respectively, we come across with such situations as described below:

In A1 level, average number of words in a sentences is 5,2.

According to the findings of Cohesion Measurement Tool used in the research, 92 words were misspelt in 382 sentences containing 1989 words by A1 level students $(4,15 \%)$. The most frequent misspellings are "şemdi (şimdi $>$ Ing. "now"), Türkiy, Türky (Türkiye $>$ Ing. "Turkey”), Felistin, ayne (ayna $>$ Ing. "mirror"), yiş̧̨l, yişillik (yeşil >Ing. "green"), bene (bana>Ing."(to) me")," etc.

Incorrect usage of infinitive structures in Turkish is often observed at this level:

- $\quad T r$. "Ben çok sevmek istiyor okumak (Ben okumayı çok sevmek istiyorum)

- Ing. "I so much to love want reading (I want to love reading so much) ..."

- $T r$. "Hayat renkli tatmak çalışıyor (Hayatı renkli yaşamak için çalışıyorum)...

- Ing. "Life colorful taste try (I try to live life colorfully)..."

Transfer factors are relatively few and students repeated the pronouns continuously:

"A few months ago my life went very happily and I then did not ask for anything because there, in the distant, I have a family and I..."

Similarly, substitution and ellipsis is not a notion that usually takes place in students' texts.

In the notion of substitution, students' written texts are quite weak. Substitution factors barely exist and the ones that

2 The examples in the study are taken originally from the written texts of students and the corrected forms in Turkish are stated in brackets. exist go to the question itself that was asked to students. For example, when "Syria" is used in the question, "Tr. ora, orada, uzakta (Ing. there, that place, distant)" are used; and when "Turkey" is used in the question, "Tr. burasl, bura, burada (Ing. here, this place, over here)" are used in the answer. Besides, in students' texts, noun phrases are repeated much the same and rewritten without using substitution:

$T r$. Birkaç ay önce benim hayatım çok mutlu geçti ve ben o zaman hiçbir şey istemedim çünkü orada, uzakta ailem var ve ben..."

Ing. "A few months ago my life went very happily and I then did not ask for anything because there, in the distant, I have a family and I..."

In the context of linguistic copying, when composing plural forms, students transferred the structures from their mother tongues into Turkish verbatim. In plural forms, in contrast to the morphology of Turkish, students compose both phrases of structures in plural:

$T r$. "Dünyanın birçok güzel şehirler var biliyorum ama benim için Halep dünyanın en güzel şehridir.

Ing. "I know there are many beautiful cities in the world but for me Aleppo is the most beautiful city in the world.

Tr. "Halep'te çok lokantalar ve çarşılar var."

Ing. There are many restaurants and shops in Aleppo.

Among conjunctions, students use "and" most frequently, and for the other conjunctions that provide temporal succession, we observe "after that, then". The conjunctions "because, but" are used rarely and conjunctions used in this regard are side order conjunctions:

$T r$. "Halep'in yemekleri baharatlı, özel ve çok lezzetli."

Ing. "Aleppo dishes are spicy, special and very delicious." $T r$. "Fırat nehir ve büyük bir köprü var."

Ing. "Euphrates is river and there is a big bridge."

$\operatorname{Tr}$. "...her yer yeşil ve utantik..."

Ing. "...every where is green and authentic ..."

$\operatorname{Tr}$. "...meyveleri ve sebzeleri..."

Ing. "...its fruits and vegetables ..."

$\operatorname{Tr}$. "Turistler daima yemeklerden yiyorlar ve eğleniyorlar."

Ing. "Tourists always eat the food and have fun."

$T r$. "İstanbul şehirine gittim çünkü ablam vard.",

Ing. "I went to city of Istanbul because my sister was there."

$T r$. "Suriye'ye döndüm, bir buçuk ay ailemde kaldım sonra yine İstanbul'a geldim."

Ing. "I returned to Syria, stayed at my family for one and a half months then came back to Istanbul."

$T r$. "Ondan sonra bir ticaret şirketinde iş buldum."

Ing. "After that I found a job in a trade company."

$T r$. Mimarlık istiyordum ama olmadı ve Niğde üniversitesi iktisat bölümünü kazandım.

Ing. I wanted to study architecture but it did not happen and I get into Niğde University Economics Department.

Among 382 sentences in A1 level texts, 238 coherence relations have been determined. Coherence relations are 
based on resemblance (133), Cause-Effect (65) and Contiguity (40) relations.

Table 2. A1 level coherence structure

\begin{tabular}{|c|c|c|c|}
\hline & & \multicolumn{2}{|c|}{ A1 Level } \\
\hline \multirow{6}{*}{$\begin{array}{c}\text { Resemblance } \\
\text { Relations }\end{array}$} & Parallel & 63 & \multirow{6}{*}{$\begin{array}{c}133 \\
(\% 55,9)\end{array}$} \\
\hline & Contrast & - & \\
\hline & Exemplification & 12 & \\
\hline & Generalization & 6 & \\
\hline & Exception & - & \\
\hline & Elaboration & 52 & \\
\hline \multirow{4}{*}{$\begin{array}{c}\text { Cause-Effect } \\
\text { Relations }\end{array}$} & Result & 24 & \multirow{4}{*}{$\begin{array}{c}65 \\
(\% 27,3)\end{array}$} \\
\hline & Explanation & 22 & \\
\hline & Violated Expectation & 19 & \\
\hline & Denial of Preventer & - & \\
\hline Contiguity & Contingency & 40 & $\begin{array}{c}40 \\
(\% 16,8)\end{array}$ \\
\hline
\end{tabular}

Average number of words in a sentence in B1 level is 7,87 .

The number of misspelt words in the database of 2733 words in B1 level written texts is $56(2,04 \%)$. The most frequent misspellings are "pişmen (pişman), diğiştireceğim (değiştireceğim), başk (başka), babam duymama (babamın duymamasl), yaramazlıktan (yaramazlı̆̆ından)" etc.

Usage of infinitive structures decreases and usage of clauses (noun and adjective clauses) increases among B1 level students:

$T r$. "babam duymama için kıs sesle, keşke babam olsaydı diyorum" [error]

Tr. (Babamın duymaması için kısık sesle, keşke babam olsaydı diyorum) [true]

Ing. "in order for my father not to hear, with hoarse voice, I say I had a father"

$T r$. "Hayatımız bir çoğu şey..." [error]

$\operatorname{Tr}$. (Hayatımızdaki birçok şey) [true]

Ing (Many things in our life)

Errors seen in plural patterns at A1 level are not observed at B1 level:

$T r$. "Iki hafta boyunca benimle konuşuyordu."

Ing. "He/she spoke with me for two weeks."

$T r$. "İki yıl sonra bir çocuğum oldu."

Ing. "I had a child after two years."

When it comes to reference, B1 level students are able to apply the already available pronoun-drop structure in their mother tongues into Turkish as well. In this respect, it is possible to come across with almost every type of references:
Tr. "Hayatımızda büyük hatalar yapıyoruz ve $b u$ hatalar..."

Ing. "We make big mistakes in our life and these mistakes ..."

$T r$. "Okuldan eve geliyorum. O gün benim için çok zordu."

Ing. "I come home from school. That day was difficult for me."

Tr. "Onlara göre markalı ürünler daha güzel. Marka takintisı olanlar iyice yayıldı."

Ing "For them branded products are nicer. Ones with brand obsession expanded much."

In the usage of conjunctions, again, the most frequently used ones are co-ordinate conjunctions. (Tr.: ve, ile, çünkü, ama...vb. Ing.: and, with, because, but, etc...):

$T r$. "Uzakta ailem var ve en iyi arkadaşlarım var ve en önemlisi..."

Ing. "In the distant, I have a family and I have best friends and most importantly..."

$T r$. "Çünkü ben önceden mühendislik bölümüne başladım."

Ing. "Because I started engineering department earlier."

$T r$. "Reklamcilık bölümünü kabul etmişti ama sevmedim çünkü...”

Ing. "He/She accepted advertisement department but I did not like because..."

$T r$. "Ama benim ailem üniversitede eğitimimi tamamlama istiyor."

Ing. "But my family wants me to complete my education at university."

Besides coordinate conjunctions, discourse markers are encountered too:

$T r$. "Keşke Suriye'ye geri dönsem."

Ing. "I wish I go back to Syria."

Tr. "Keşke bu olay tekrar olsa."

Ing. "I wish this incident happens again."

Tr. "Keşke keşkeler olmasaydı."

Ing. "I wish there were no 'I wish'es"

$T r$. "Maalesef vatanımdan ayrıldım."

Ing. "Unfortunately I left my homeland."

$T r$. "Buna rağmen işletmeye okudum."

Ing. "In spite of this, I studied management."

B1 level students cannot apply the rule of changing the affixes according to the vowel harmony exactly the same as A1 level students: "reklamcılık (reklamcilık), hayatımde (hayatımda), seçmaz (seçmez), one (ona)...etc."

Upon analyzing the coherence relation, among 347 sentences in A1 level texts, 352 coherence relations have been determined. The types of relations mostly used among coherence relations are; resemblance (173), Cause-Effect (116) and Contiguity (63) relations respectively: 
Table 3. B1 level coherence structure

\begin{tabular}{|c|c|c|c|}
\hline & & \multicolumn{2}{|c|}{ B1 Level } \\
\hline \multirow{6}{*}{$\begin{array}{c}\text { Resemblance } \\
\text { Relations }\end{array}$} & Parallel & 52 & \multirow{6}{*}{$\begin{array}{c}173 \\
(\% 49,14)\end{array}$} \\
\hline & Contrast & 5 & \\
\hline & Exemplification & 40 & \\
\hline & Generalization & 14 & \\
\hline & Exception & 4 & \\
\hline & Elaboration & 59 & \\
\hline \multirow{4}{*}{$\begin{array}{l}\text { Cause-Effect } \\
\text { Relations }\end{array}$} & Result & 46 & \multirow{4}{*}{$\begin{array}{c}116 \\
(\% 32,96)\end{array}$} \\
\hline & Explanation & 45 & \\
\hline & Violated Expectation & 21 & \\
\hline & Denial of Preventer & 4 & \\
\hline Contiguity & Contingency & 63 & $\begin{array}{c}63 \\
(\% 17,9)\end{array}$ \\
\hline
\end{tabular}

Average number of words in a sentence in C1 level is 9,48. 29 words out of 2856-word database in C1 level were misspelt (1,01\%). These are "madem ki (mademki), oysa ki (oysaki), atasöz (atasözü), hemde (hem de) örğendiği (öğrendiği), dile (dille), kuför (kuaför), barber (berber), türkey ...etc." Also, mistakes regarding the failure of capitalization of the first letter of proper nouns are observed. "türkçe, türkey, fransızca...etc.".

The ratio of conjunction usage in $\mathrm{C} 1$ level students is quite low. Phrases are usually connected to each other by using conjunctions that are in the form of affixes, such as (-meden, -mediğim, -duğu zaman, -meden önce...etc.). Conjunctions that are in the form of words are also used, such as " $T r .: v e$, çünkü, ama, keşke, bu yüzden, hatta, tabii ki, neyse > Ing.: and, because, but, if only, "therefore, even, surely, anyway".

Apart from reference, alteration structures are also observed in $\mathrm{C} 1$ students:

Tr. "...hemde ikisi de Müslüman bu yüzden bizi birbirimize çok yaklaştırıyor"

Ing. "... also both of them are Muslim therefore it makes us approach to each other much"

In the usage of conjunctions, there are varieties in the usage of discourse markers in addition to coordinate conjunctions as mentioned:

$T r$. "Fransızca bölümünde girdim tabiki o süre çok mutlu oldum."

Ing. "I get into the French department of course I became very happy at that moment."

$T r$. “...vatanımda savaş başladı neyse türkeyi (Türkiye’ye) geldiğimde...

Ing. "...war broke out in my homeland anyway when I came to turkey ...

$T r$. "türkçe çok zengin bir dil hatt (hatta) ben türkçe konuşurken..."

Ing. "turkish is a very rich language even when I speak turkish..."
In respect with coherence relations, in $\mathrm{C} 1$ level, 372 coherence relations were determined among 301 sentences. Turkish language may present more than one relation in one sentence in some complex structures:

$T r$. "...çok mutlu oldum ama maalesef okul bitmeden vatanımda savaş başladı."

Ing. "...I became very happy but unfortunately war broke out in my homeland before school finished."

In the sample structure above "become happy" introduces a result relation, and "I became very happy but unfortunately war broke out in my homeland before school finished" introduces a violated expectation relation.

The most frequently used relations among coherence relations are; resemblance (175), Cause-Effect (125) and Contiguity (72) relations successively:

Table 4. $\mathrm{C} 1$ level coherence structure

\begin{tabular}{|c|c|c|c|}
\hline & & \multicolumn{2}{|c|}{ C1 Level } \\
\hline \multirow{6}{*}{$\begin{array}{c}\text { Resemblance } \\
\text { Relations }\end{array}$} & Parallel & 48 & \multirow{6}{*}{$\begin{array}{c}175 \\
(\% 47,04)\end{array}$} \\
\hline & Contrast & 8 & \\
\hline & Exemplification & 41 & \\
\hline & Generalization & 22 & \\
\hline & Exception & 6 & \\
\hline & Elaboration & 50 & \\
\hline \multirow{4}{*}{$\begin{array}{c}\text { Cause-Effect } \\
\text { Relations }\end{array}$} & Result & 36 & \multirow{4}{*}{$\begin{array}{c}125 \\
(\% 33,6)\end{array}$} \\
\hline & Explanation & 53 & \\
\hline & Violated Expectation & 27 & \\
\hline & Denial of Preventer & 9 & \\
\hline Contiguity & Contingency & 72 & $\begin{array}{c}72 \\
(\% 19,36)\end{array}$ \\
\hline
\end{tabular}

Looking at the common problems observed in every level, we see that haplology notion is not understood in any of the levels (A1, B1 and C1) and haplology is not observed; "şehiri, karınını" ...etc. Moreover, at the beginning of the sentences the words begin in capital letters but the rule of proper nouns beginning with capital letters is not observed in every level.

\section{Results and Discussion}

Constructed sentences of A1 level students contain approximately 5 to 6 words. Sentences are connected to each other by using side by side ordering conjunctions. This shows that the students prefer simple sentences in terms of the sentence structure and have not yet comprehended co-ordinate sentence structures. Considering that education should start from simple and continue on to complex, it is naturally expected that students construct such sentences.

Misspellings by students are generally a result of negative copying. Students associated the words in the target language to the ones in their mother tongues. For example, the word "Tr. şimdi (Ar. نآل)", has a similar pronunciation in Arabic, 
therefore we see that the first sound was changed into "e" when writing in Turkish. In the next example, the effect of English is high in making the resemblance. The spelling of "Turkey" indicates that there is a negative effect of English and students spell the word as "Türkiy or Türky" in the written texts. In this respect, there is a tendency for the student to resemble, copy the words in the target language and apply it to the mother tongue or another language in his/her background. This situation should be considered natural among individuals learning a foreign language, especially at the beginning level.

A1 level Syrian students use infinitives in Turkish frequently. Even though Arabic and Turkish have similarities, they are different languages in the end. Arabic is an inflexible language, whereas Turkish is an agglutinative language. The reason that the first level students are not familiar with the agglutinative language structure, they used infinitive structures often since this is the easiest way to make additions, and maybe, it could also be resulted from the fact that this the first type of addition they are taught. Particularly, we see this in the usage of "bene (Tr. bana >Ing. (to) me)"; the Turkish word "bana" that acts like the inflexible structure of Arabic is written as "bene" by Syrian students in order to adapt it to the agglutination process of Turkish.

Reference elements are not frequent in students' texts. References are made to the question itself, out of text reference. As the reference does not occur, word repetitions, like noun phrases and pronouns, are made within the text. Although Arabic is a pro-drop language similar to Turkish, it is a subject of discussion why students cannot comprehend this situation at the beginning level.

In terms of coherence relations, the fact that students used structurally simple phrases caused the number of sentences to increase compared to the number of coherence relations. Considering the coherence relations by kind, frequent usage of resemblance relations is of the characteristics that supports this situation. In fact, resemblance relations allow fictions that could only be considered basic in terms of principal way of thinking.

B1 level students, in average, started to use 7,87 words in a sentence. Compared to A1 level, the average number of words in a sentence is increased. This situation shows that the students started to make more complex structures and their vocabulary gradually increased.

B1 level students whose misspellings decreased gradually tend to narrow (mostly i) the open vowels (mostly e) in the words. It is possible to mention a general $e>i$ change in $\mathrm{B} 1$ level. In Arabic fetha "-_, kesra "-," and damme "-," state short vowels. According to this, fetha is used for "a" and "e", and kesra is used for " $i$ ". Possible e $>i$ change can be an indication of students not being able to transfer the difference in related letters into Turkish yet. Besides, misspellings are far from word roots; they are mostly about the usage of affixes seen in noun clauses. It can be stated that since Turkish followed a different way form a word than Arabic caused this type of mistakes continued in B1 level as well.

In B1 level, usage of infinitive has been replaced slowly by noun phrases, however, mistakes occurred in the usage of affixes in noun phrases. Especially in noun phrases correct usage of determinant and determined affixes are not seen much. This can be explained with different ways of word formation in language structures. Syrians whose mother tongue is Arabic may have similar problems when they come across with a language that has different word formation. In fact, situations of Syrian students who learn foreign languages other than Turkish should be analyzed separately.

Mistakes observed in plurality structures in A1 level disappeared completely in B1 level. Therefore, students did not make mistakes when using some collective nouns, "Tr. bazı insanlar (Ing. some people)".

Usage of co-ordinate conjunctions is quite high among all conjunctions. But different from A1 level, usage of " $T r$. ama, çünkü, fakat (Ing. but, because, however)" conjunctions increased in addition to "Tr. ve (Ing. and)" conjunction. Thus, it is expected to have a similar change in the coherence relations. Such that these conjunctions are the formal aspects of coherence relations such as violated expectation, explanation, and contrast relations. Besides, too many usages of "Tr. keşke (Ing.I wish)" and "Tr. maalesef (Ing. unfortunately)" as a discourse marker are a linguistic expression of a societal problem for Syrians taking refuge in Turkey. This result can be specifically a subject of a separate study from a sociolinguistic perspective, however considering the current situation as super structural and except for the conjunction of the text, it is quite possible to say that feeling of longing in Syrian students predominates.

It is an expected result that the average number of words in a sentence is the highest in $\mathrm{C} 1$ level compared to other levels and the average number of words increases as the level gets more advanced.

The number of misspelt words also decreased. The length of the process and duration of interaction with Turkish as a foreign language, interaction of students concretely with more Turkish inputs (such as social and cultural environments besides their educational environments) brought along this decrease in misspellings. Misspellings in conjunctions can often be observed among the native speakers of Turkish because these misspellings are common for them as well. Also, students interacting with the social environment started to use foreign words that take place in Turkish (even if the usage is wrong). These words are the ones they did not learn during their language education; such as "barber (berber)". This shows that foreigners that learn Turkish are also affected by the "incorrect usage of foreign words" or "foreign word imitation" problem that are frequently seen in billboards and signs in Turkey.

Students that can make references, can often make alterations in Turkish too. The increase in average number of words and the usage of alteration elements can be explained with the efficient usage of conjunctions, so the variety of the conjunctions increased as well. 
The higher number of coherence relations when compared to number of sentences can be explained with the fact that students make more complex structures and they can fictionalize different coherence relations in one sentence. This is also in line with the typological structure of Turkish. Turkish language can contain more than one coherence relations within a sentence. In parallel with this result, the efficient usage of conjunctions as affixes is increased. These two results are consistent with each other.

In general usage of coherence relations, while resemblance relations are more frequently used in A1 level, their usage decreases gradually through $\mathrm{B} 1$ and $\mathrm{C} 1$ levels. However, in A1 level texts "contrast" and "exception" relations are never used as they require higher level of thinking skills (compared to parallel and elaboration). Exception and contrast usages are encountered in B1 and C1 levels in an increasing fashion and this shows that students, during their language learning process, started to internalize the language and realizes their higher thinking skills in the foreign language as well. The increase in cause-effect relations is consistent with this situation as the level gets higher. In the usage of contiguity relations, the number of usage gets lower as the level gets higher. Considering each level and three thinking types, the usage of resemblance and contiguity relations decrease while cause-effect relations increase. It can be stated that Syrians learning Turkish improve their thinking skills related to the target language as the level increases. However, this assumption, if and only, is possible by determination of how individuals, whose mother tongues are Arabic and Turkish and whose educational levels and ages are the same, use coherence relations and by comparing the results afterwards. With the implementation of this kind of studies on world languages, thinking skills in languages and reflections of these skills on linguistic coding shall be designated.

\section{Annex}

\section{Cohesion Measurement Tool}

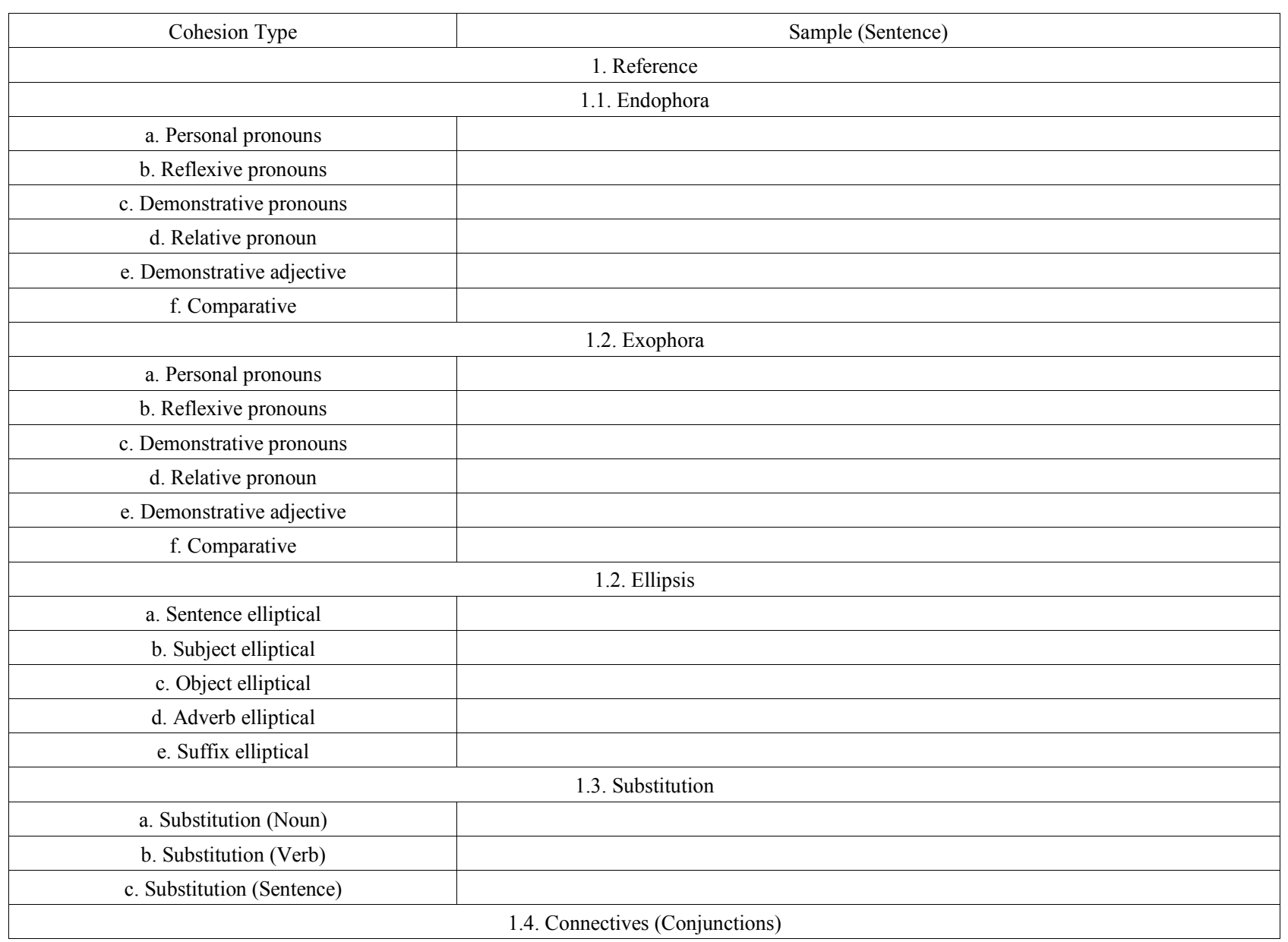




\section{REFERENCES}

[1] Ada, S. ve Şahenk, S. S. (2010). Avrupa Dil Portfolyosu ve Türkiye'de Yabancı Dil Eğitimi. Avrupa Araştırmaları Dergisi, Cilt 18, Sayı: 1-2. 63-88.

[2] Ağar, M. E. (2004). Türkçe Öğretiminin Tarihçesi. Uluslararası İnsan Bilimleri Dergisi, 1, 1-10.

[3] Council of Europe - Avrupa Konseyi / Modern Diller Bölümü, (2013). Diller İçin Avrupa Ortak Başvuru Metni (Öğrenme-Öğretim ve Değerlendirme). (2. Bask1), Frankfurt/Main, Almanya.

[4] Beaugrande, R. ve Dressler, W. U. (1988). Introduction to Text linguistics, Fourth edition, Longman, London.

[5] Connor,U. (1996). Contrastive Rhetoric: Cross-Cultural Aspects of Second Language Writing. Cambridge University Press: United Kingdom.

[6] Council of Europe (2007). Common European Framework of Reference for Languages. Learning, Teaching, Assessment. USA: Cambridge University Press.

[7] Council of Europe. (1993). Transparency and coherence in language learning in Europe: Objective, assessment and certification Report on the Ruschlikon Symposium .CC LANG, 19, 22.

[8] Çelik, T (2015). Evaluation of private writing from the student's viewpoint. International J. Soc. Sci. \& Education Vol.5 Issue 2, 269-279.

[9] Flower, L. \& Hayes, J. (1980). The dynamics of composing: Making plans and juggling constraints. In L. Gregg \& E. Steinberg (Eds.). Cognitive processes in writing (31-50). Hillsdale, NJ: Lawrence Erlbaum Associates.

[10] Flower, L. \& Hayes, J. (1981). A cognitive process theory of writing.College Composition and Communication, 32, 365-387

[11] Günay, D. (2013). Metin Bilgisi. İstanbul: Papatya Yayıncılık (4. Bask1)
[12] Halliday, M. \& Hasan, R. (1976). Cohesion in English. New York: Longman Group UK. Limited.

[13] Hengirmen, M. (1997). Yabancı Dil Öğretim Yöntemleri ve TÖMER Yöntemi. Ankara: Engin Yayınevi.

[14] Karataş, Y. (2008). Metin Bağdaşıklığı Açısından Arapçada Gönderim Olgusu. Usûl İslam Araştırmaları Dergisi, Sakarya Üniversitesi İlahiyat Fakültesi.

[15] Kurtul, K. (2011). Türkçe ve İngilizce'deki Bağlaçların Yazılı Metinlerde Kullanımı, Yayımlanmamış Doktora Tezi, Ankara Üniversitesi Sosyal Bilimler Enstitüsü, Ankara.

[16] Johanson, J. (2002). Do languages die of 'structuritis'? On the role of code-copying in language endangerment. Italian Journal of Linguistics, Vol.:14. No.:2.

[17] Kehler, A. (2002). Coherence, Reference and the Theory of Grammar. USA: CSLI Publications.

[18] Omaggio Hadley, A. (1993). Teaching language in context. Boston: Heinle \& Heinle.

[19] Pifarré, M. \& Fisher, R. (2011). Breaking up the writing process: how wikis can support understanding the composition and revision strategies of young writers, Language and Education, 25:5, 451-466, DOI: $10.1080 / 09500782.2011 .585240$

[20] Robatjazi, M. A. (2008). Language education: Intercultural communicative competence and curriculum. University of Mysore.

[21] Swales, J. (1990). Genre analysis: English in academic and research settings. Cambridge, England: Cambridge University Press.

[22] Taylor, R. (2014) Meaning between, in and around words, gestures and postures - multi modal meaning-making in children's classroom discourse, Language and Education, 28:5, 401-420, DOI: 10.1080/09500782.2014.885038

[23] Zeyrek, D.,Webber, B. (2008). A Discourse Resource for Turkish: Annotating Discourse Connectives in the METU Corpus. 